\title{
Influences of Chemical Fertilizers and a Nitrification Inhibitor on Greenhouse Gas Fluxes in a Corn (Zea mays L.) Field in Indonesia
}

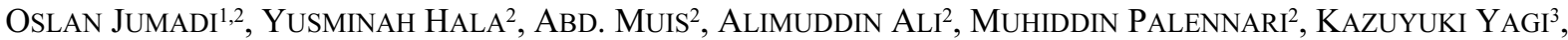 \\ and KAZUYUKI INUBUSHI* \\ ${ }^{1}$ Graduate School of Science and Technology, and ${ }^{4}$ Graduate School of Horticulture, Chiba University, Matsudo, \\ 271-8510 Japan; '2Department of Biology, Faculty of Mathematics and Natural Science, Makassar State University, \\ Makassar, South Sulawesi 90224, Indonesia; and ${ }^{3}$ National Institute for Agro-Environmental Science (NIAES), \\ Tsukuba, Ibaraki 305-8604, Japan
}

(Received May 26, 2007-Accepted September 30, 2007)

The influences of chemical fertilizers and a nitrification inhibitor on greenhouse gas fluxes $\left(\mathrm{N}_{2} \mathrm{O}\right.$ and $\left.\mathrm{CH}_{4}\right)$ in a corn field in Indonesia were investigated using a closed chamber. Plots received $45+45 \mathrm{~kg}-\mathrm{N} \mathrm{ha} \mathrm{h}^{-1}$ of nitrogen fertilizer by split applications of urea, a single application of controlled-release fertilizer (CRF-LP30) or urea+dicyandiamide (DCD; a nitrification inhibitor), and no nitrogen application (control). Cumulative amounts of $\mathrm{N}_{2} \mathrm{O}$ emitted from the field were 1.87, 1.70, 1.06, and $0.42 \mathrm{~kg} \mathrm{~N}_{2} \mathrm{O}-\mathrm{N} \mathrm{ha}{ }^{-1}$ season ${ }^{-1}$ for the urea, CRF-LP30, urea+DCD, and control plots, respectively. The application of urea+DCD reduced the emission of $\mathrm{N}_{2} \mathrm{O}$ by $55.8 \%$ compared with urea. On the other hand, the soil acted as a sink for $\mathrm{CH}_{4}$ in the CRL-LP30, control, and urea+DCD plots with value of $-0.09,-0.06$ and $0.06 \mathrm{~kg} \mathrm{CH}_{4}-\mathrm{C} \mathrm{ha}^{-1}$ season $^{-1}$, respectively. When the viability of AOB (ammonia-oxidizing bacteria) and NOB (nitriteoxidizing bacteria) were monitored, $\mathrm{AOB}$ numbers were correlated with the $\mathrm{N}_{2} \mathrm{O}$ emission. These results suggest that 1) there is a potential for reducing emissions of $\mathrm{N}_{2} \mathrm{O}$ by applying DCD, and 2) corn fields treated with CRF or urea+DCD can act as a sink for $\mathrm{CH}_{4}$ in a tropical humid climate.

Key words: Indonesia upland soil, nitrification inhibitor, nitrifier population

The use of nitrogen $(\mathrm{N})$ fertilizers increases the amount of available $\mathrm{N}$ in the soil and improves the productivity of agricultural crops. However, up to about $60 \%$ of $\mathrm{N}$ fertilizers can be lost through leaching of mobile $\mathrm{N}$ compounds such as nitrate $\left(\mathrm{NO}_{3}^{-}\right)$and evolution as nitrous oxide $\left(\mathrm{N}_{2} \mathrm{O}\right)$ and dinitrogen $\left(\mathrm{N}_{2}\right)$. $\mathrm{N}_{2} \mathrm{O}$ is a greenhouse gas $(\mathrm{GHG})$, and also an ozone layer disrupting gas ${ }^{28,30)}$.

Nitrogen is a key limiting factor for the growth of crops as well as soil microorganisms, and the addition of $\mathrm{N}$ can affect microbial biomass, activity, and species composition ${ }^{4,19,31)}$. Most of the nitrogen fertilizers applied to soils are in the form of ammonium $\left(\mathrm{NH}_{4}^{+}\right)$or ammonium-producing compounds such as urea and organic manure. Nitrification, the oxidation of $\mathrm{NH}_{4}{ }^{+}$to $\mathrm{NO}_{3}{ }^{-}$by nitrifiers, affects the fate of $\mathrm{N}$ fertilizers. Nitrification in the soil is considered to be one of the main processes for increasing $\mathrm{N}_{2} \mathrm{O}$ levels in the atmosphere and ammonia-oxidizing bacteria (AOB) appear to be important in this process.

About $90 \%$ of $\mathrm{N}_{2} \mathrm{O}$ produced was derived from autotrophic nitrification in aerobic soil at $60-80 \%$ water holding capacity ${ }^{15}$. Meanwhile, AOB may also be involved in the oxidization of atmospheric methane in aerobic soils, since methane is an alternative substrate for ammonia monooxygenase $e^{3,18,23,33)}$. Therefore, upland soil is thought to contribute to the oxidation of $\mathrm{CH}_{4}{ }^{23)}$. However, upland soils with low $\mathrm{CH}_{4}$ production also exist, particularly when the soil becomes wet or there is ammonia at the surface rather than in the subsoil which may cause inhibition of $\mathrm{CH}_{4}$

\footnotetext{
* Corresponding author. E-mail: inubushi@faculty.chiba-u.jp;

Tel: +81-47-308-8816; Fax: +81-47-308-8720.
}

oxidation $^{23)}$. Therefore, the application of nitrification inhibitors may have some influence on the oxidation of methane in soil.

Most AOB fall within one taxonomic group in the $\beta$-subclass of the Proteobacteria and seven clusters based on 16S rRNA gene sequences are currently recognized in this group $^{22)}$. The AOB utilized ammonium as a substrate to produce nitrite via the intermediate hydroxylamine. Two gases, $\mathrm{NO}$ and $\mathrm{N}_{2} \mathrm{O}$, are produced in smaller amounts relative to the amount of ammonia oxidized, but their release into the atmosphere has significant consequences ${ }^{3}$.

A potentially effective strategy for reducing emissions of $\mathrm{N}_{2} \mathrm{O}$ would be the inhibition of nitrification and denitrification. The rates at which these processes emit $\mathrm{N}_{2} \mathrm{O}$ depend on the amount of $\mathrm{NH}_{4}{ }^{+}$and $\mathrm{NO}_{3}{ }^{-}$in the soil as well as other factors including soil water content, organic matter, temperature and $\mathrm{pH}^{17,19,24,28)}$. Therefore, it might be expected that, in the worst-case scenario, agricultural land should be managed intensively in a climate under both warm and wet soil conditions with frequent fluctuations between wet and dry.

Nitrification inhibitors have been used in the field to improve the efficiency of fertilizers and to reduce both nitrate leaching and denitrification by maintaining the $\mathrm{N}$ in the soil as $\mathrm{NH}_{4}^{+9,34)}$. Dicyandiamide (DCD) acts as a nitrification inhibitor by inhibiting the first stage of the nitrification process, the oxidation of $\mathrm{NH}_{4}^{+}$to $\mathrm{NO}_{2}^{-}$, and by rendering bacterial enzymes ineffective ${ }^{6}$. Therefore, DCD can be regarded as a slow release $\mathrm{N}$ fertilizer (containing about $65 \%$ $\mathrm{N}$ ). In addition, DCD is non-toxic, non-hygroscopic, and non-volatile and therefore has been considered a suitable combination with solid fertilizers. Moreover, DCD is not a 
bactericide, and does not affect other heterotrophs that are responsible for much of the biological activity in soil ${ }^{11)}$.

Another possible way to improve efficiency is to use controlled release fertilizers (CRFs). In temperate regions, $\mathrm{CRF}$ can reduce emission of $\mathrm{N}_{2} \mathrm{O}$ and $\mathrm{NO}$ shortly after fertilization. However, no significant differences in the total amounts of $\mathrm{N}_{2} \mathrm{O}$ and $\mathrm{NO}$ emitted over 77 days was reported between $\mathrm{CRF}$ and urea ${ }^{13)}$.

Little investigation, however, has been carried out of the relationship between emissions of GHGs and populations of nitrifiers in upland fields in tropical regions such as Indonesia. To address these issues, we conducted field studies to determine the influences of different types of $\mathrm{N}$ chemical fertilizers or nitrification inhibitors on the flux of $\mathrm{N}_{2} \mathrm{O}$ and $\mathrm{CH}_{4}$ and the population of nitrifiers during a cropping season in a corn field in Makassar, Indonesia.

\section{Materials and Methods}

\section{Field site and soil analysis}

Corn (Zea mays L.) seeds were sown in a well drained field of Makassar State University in Makassar, South Sulawesi, Indonesia ( $5 \mathrm{~m}$ asl., $05^{\circ} 11.221^{\prime} \mathrm{S} 11^{\circ} 25.750^{\prime} \mathrm{E}$ ) on October 15,2005 and harvested on January 8,2006 or 83 days after $1^{\text {st }}$ fertilization (DAF).

Three replicates of four treatments were laid out in a completely randomized design. The field has an area of around $48 \mathrm{~m}^{2}(6 \mathrm{~m}$ wide $\times 8 \mathrm{~m}$ long) and each microplot measures $1.8 \mathrm{~m}^{2}(1.2 \mathrm{~m}$ wide $\times 1.5 \mathrm{~m}$ long). The arrangement of the plots in the field is shown in Fig. 1.

The soil was classified as Haplusterts, which was described as an Alluvial soil type (Center for Soil and Agroclimate Research, Indonesia, 2000). Before this experiment started, the soil had a $\mathrm{pH}$ $\left(\mathrm{H}_{2} \mathrm{O}\right)$ of 5.7 , EC of $5.0 \mathrm{mS} \mathrm{m}{ }^{-1}$, total carbon content of $15.4 \mathrm{~g}-\mathrm{C}$ $\mathrm{kg}^{-1}$, total $\mathrm{N}$ content of $2.1 \mathrm{~g}-\mathrm{N} \mathrm{kg}^{-1}$ dry soil, and $\mathrm{C} / \mathrm{N}$ ratio of 7.32 , measured by electrode methods and a C/N analyzer (MT 700 Yanaco, Kyoto, Japan), respectively. Soil moisture was determined by the oven drying method $^{8}$. The average annual amount of rainfall and annual air temperature were around $2364 \mathrm{~mm}$ and $21.5-34.2^{\circ} \mathrm{C}$, respectively. The wet season is generally October to March and the dry season is from April to September. The data on daily temperature and precipitation were collected from the bureau of Meteorological and Geophysical of Makassar, Indonesia. Average temperature during the experiments was $22-32^{\circ} \mathrm{C}$.

The nitrogen fertilizer types applied in the field were urea, a controlled-release fertilizer (CRF-LP30; designed to release $80 \%$ of applied nitrogen at $20^{\circ} \mathrm{C}$ over at least 30 days, Chissoasahi Fertilizer Co., Ltd., Kumamoto, Japan), and Urea+dycianodiamide [DCD; a nitrification inhibitor was mixed with urea at a rate of $10 \%$ of urea $\mathrm{N}(\mathrm{w} / \mathrm{w})]$. The rate of $\mathrm{N}$ applied in each treatment was $45+45 \mathrm{~kg}-\mathrm{N} \mathrm{ha}{ }^{-1}$ applied in two splits on October 15 , and November 30, 2005. Plots without $\mathrm{N}$ application were also set up as a control.

Soil samples were taken from triplicate plots at a depth of $0-10$ $\mathrm{cm}$ and sieved through $2.00 \mathrm{~mm}$ mesh to analyze the $\mathrm{NH}_{4}{ }^{+}$and $\mathrm{NO}_{3}{ }^{-}$contents of the soil. Five grams, on an oven dried basis, of fresh soil was weighed into a 50 -ml plastic bottle with a screw cap. Soils were immediately extracted with $25 \mathrm{ml}$ of $0.5 \mathrm{M} \mathrm{K}_{2} \mathrm{SO}_{4}$ (1:5) solution by shaking for $30 \mathrm{~min}$ on reciprocal shaker and filtered with filter paper (Advantec No. 6, Tokyo, Japan). The amounts of $\mathrm{NH}_{4}{ }^{+}$and $\mathrm{NO}_{3}{ }^{-}$were determined by the nitroprusside and hydrazine reduction methods, respectively ${ }^{2,12)}$.

The viable populations of nitrifiers; i.e. ammonium oxidizers (AOB) and nitrite oxidizers (NOB), were estimated by the most probable number (MPN) method ${ }^{32)}$. The inoculants were prepared as follows; 10 grams of fresh soil and $90 \mathrm{ml}$ of sterile phosphate buffer were placed in a sterile bottle (for each composite soil sam-
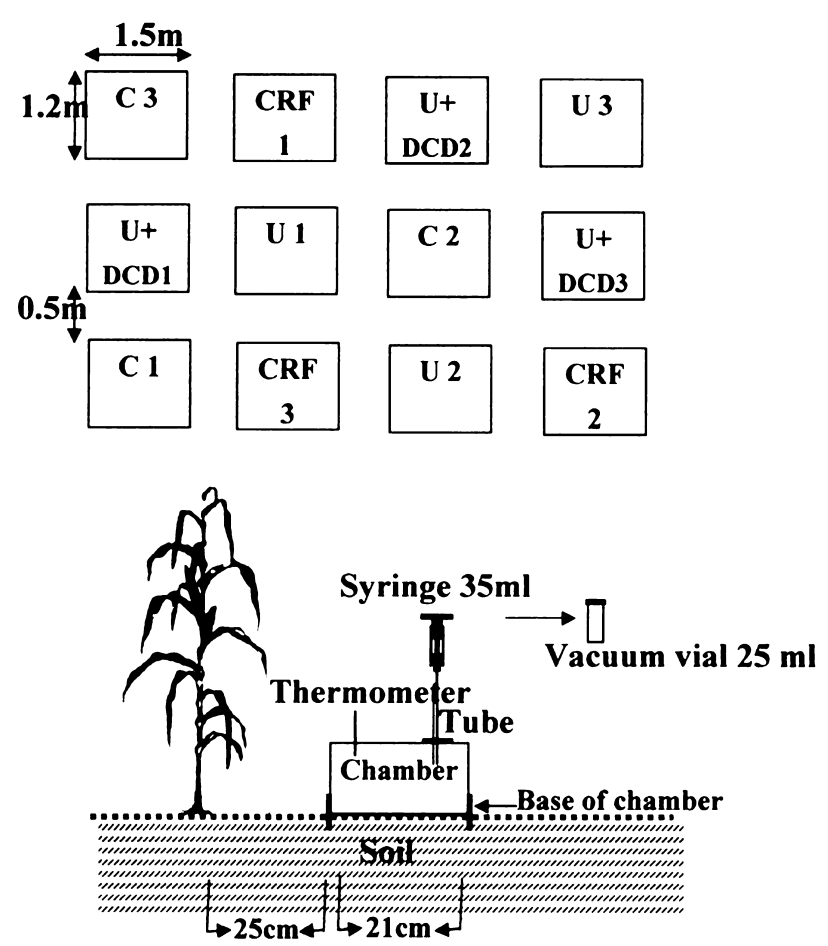

Fig. 1. Arrangement of experimental plots and position of the chamber in each plot. Corn was harvested on January 8, 2006 or 83 days after the first fertilization. $\mathrm{C}=\mathrm{C}$ ontrol, $\mathrm{U}=\mathrm{Urea}, \mathrm{CRF}=\mathrm{Control}$ release fertilizer and $\mathrm{U}+\mathrm{DCD}=\mathrm{Urea}+\mathrm{DCD}$.

ple) and shaken vigorously on a wrist action shaker for $30 \mathrm{~min}$. For dilutions of $10^{3}-10^{7}$, five replicates each of the culture tubes were employed.

Means and standard deviations of the data were calculated. Each mean was compared with others using the least significant differences $(\mathrm{LSD}=0.05)$ value by SPSS software (Ver. 11.0 for windows, SPSS Inc., Chicago, USA).

\section{Nitrous oxide and methane flux measurements}

Gaseous fluxes were measured at two-day intervals throughout the cropping season using a closed chamber (inner dia. $21 \mathrm{~cm}$; height $14 \mathrm{~cm})\left(\right.$ Fig. 1) ${ }^{16)}$. The gas samples were taken from the chamber at 0,15 , and 30 minutes using disposable syringes and then immediately transferred to evacuated air glass vials with butyl rubber stoppers. The gaseous samples were taken between 10:00 and 12:00 a.m. The concentrations of $\mathrm{N}_{2} \mathrm{O}$ and $\mathrm{CH}_{4}$ in the samples were quantified using gas chromatographs (Shimadzu, GC 14B, Kyoto, Japan) equipped with an electron capture detector (ECD) and a flame ionization detector (FID), respectively ${ }^{16}$. $\mathrm{N}_{2} \mathrm{O}$ and $\mathrm{CH}_{4}$ fluxes were calculated from the change in $\mathrm{N}_{2} \mathrm{O}$ and $\mathrm{CH}_{4}$ concentrations over time, after accounting for diffusion constraints.

Cumulative $\mathrm{N}_{2} \mathrm{O}$ and $\mathrm{CH}_{4}$ fluxes per season from the field were obtained by integration of $\mathrm{N}_{2} \mathrm{O}$ and $\mathrm{CH}_{4}$ fluxes during the cropping season, respectively. Analyses were done in triplicate and means and standard deviations were calculated.

The percentage of $\mathrm{N}_{2} \mathrm{O}-\mathrm{N}$ lost per amount of $\mathrm{N}$ applied as fertilizer to the field ( $\mathrm{EF}=$ =mission factor) was calculated using the following equation ${ }^{7}$.

\section{$\mathrm{EF}(\%)=\left(T_{F}-T_{U F}\right) / N \times 100$}

where: $T_{F}$ and $T_{U F}=$ Cumulative $\mathrm{N}_{2} \mathrm{O}$ flux emitted from the nitrogen-applied plot and the non-nitrogen applied plot (control), respectively $\left(\mathrm{kg} \mathrm{N}_{2} \mathrm{O}-\mathrm{N} \mathrm{ha}^{-1}\right.$ season $^{-1}$ ) and $N=$ Total nitrogen applied in the field ( $\mathrm{kg} \mathrm{N} \mathrm{ha}^{-1}$ season $\left.^{-1}\right)$.

The percent reduction of $\mathrm{N}_{2} \mathrm{O}$ emitted from the fields with a nitrification inhibitor or CRF was calculated using the following 
equation $^{26)}$

$\mathrm{N}_{2} \mathrm{O}$ reduction $(\%)=(A-C) /(A-B) \times 100$

where $A$ is the cumulative $\mathrm{N}_{2} \mathrm{O}$ emission in the urea plot, $B$ is the cumulative $\mathrm{N}_{2} \mathrm{O}$ emission in the control plot, and $C$ is the cumulative $\mathrm{N}_{2} \mathrm{O}$ emission with a nitrification inhibitor or in the CRF plots.

\section{Results and Discussion}

\section{Nitrous oxide emissions}

$\mathrm{N}_{2} \mathrm{O}$ emissions were highest during the first 7 days after the fertilizer was applied and slowly declined thereafter (Fig. $2)$. The application of nitrogen fertilizers in the field increased the emission of $\mathrm{N}_{2} \mathrm{O}$. The maximum flux of $\mathrm{N}_{2} \mathrm{O}$ increased to $0.9 \mathrm{mg} \mathrm{N}_{2} \mathrm{O}-\mathrm{N} \mathrm{m}^{-2} \mathrm{~h}^{-1}$ two days after the first application of $\mathrm{N}$ fertilizer and then gradually decreased to around $0.05 \mathrm{mg} \mathrm{N} \mathrm{N}_{2} \mathrm{O}-\mathrm{N} \mathrm{m}^{-2} \mathrm{~h}^{-1}$. However, on the second application, a maximum flux of around $0.19 \mathrm{mg} \mathrm{N}_{2} \mathrm{O}-\mathrm{N} \mathrm{m}^{-2}$ $\mathrm{h}^{-1}$ appeared after 18 days in the urea plot. Meanwhile, the highest peak of $\mathrm{N}_{2} \mathrm{O}$ flux was $0.14 \mathrm{mg} \mathrm{N}_{2} \mathrm{O}-\mathrm{N} \mathrm{m}^{-2} \mathrm{~h}^{-1}$ at 14 days in the CRF plot and $0.17 \mathrm{mg} \mathrm{N}_{2} \mathrm{O}-\mathrm{N} \mathrm{m}^{-2} \mathrm{~h}^{-1}$ at 22 days after the second application in the urea+DCD plot (Fig. 2).
Fig. 2 shows the substantial repression of $\mathrm{N}_{2} \mathrm{O}$ flux from soils with the combination of nitrogen fertilizer and DCD under the experimental conditions. Based on the equation of Majumdar et al. ${ }^{26)}$, urea+DCD reduced $\mathrm{N}_{2} \mathrm{O}$ flux from the soil by $55.8 \%$ compared to the urea plot and by $11.7 \%$ compared to the CRF plot. The results suggest a potential for reducing $\mathrm{N}_{2} \mathrm{O}$ emissions even from nitrogen-fertilized corn fields under tropical conditions where the annual temperature is in the range of $20-35^{\circ} \mathrm{C}$.

Dobbie and Smith ${ }^{7)}$ confirmed urea+DCD plots effectively depressed the nitrification reaction in warmer periods (soil temperature of around $15^{\circ} \mathrm{C}$ ) and suggested the use of DCD with urea to be an effective way to reduce emissions from intensive grassland even under cooler conditions (soil temperature of around $4-6^{\circ} \mathrm{C}$ ).

Akiyama and Tsuruta $^{1)}$ reported that $\mathrm{CRF}$ reduced $\mathrm{N}_{2} \mathrm{O}$ emissions compared to urea, when there was heavy rainfall just after the fertilization. Therefore, seasonal changes of $\mathrm{N}_{2} \mathrm{O}$ emission are highly dependent on precipitation and soil moisture (Fig. 2).

Many studies ${ }^{1,7,13-16)}$ show that different types of nitrogen fertilizers and soil moisture conditions influence temporal

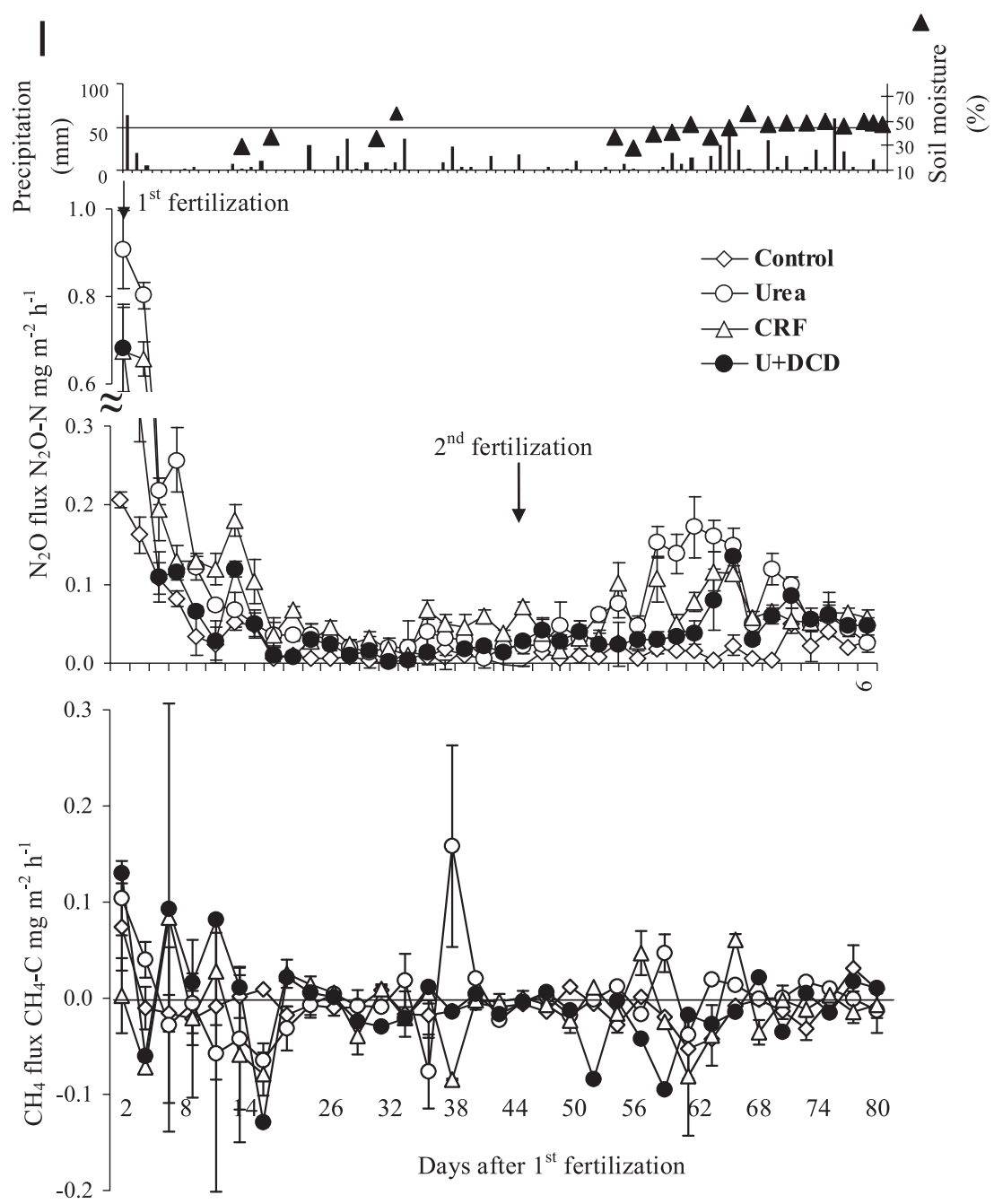

Fig. 2. Change of precipitation, soil moisture, $\mathrm{N}_{2} \mathrm{O}$, and $\mathrm{CH}_{4}$ flux from the corn field affected by different nitrogen fertilizers during the cropping season (October 2005 to January 2006). Vertical bars indicate \pm standard deviation. Corn was harvested on January 8, 2006 or 83 days after the first fertilization. See Fig. 1 for abbreviations of symbols. 
patterns of $\mathrm{N}_{2} \mathrm{O}$ emissions. In our study, the flux of $\mathrm{N}_{2} \mathrm{O}$ from a corn field was affected by the nitrogen fertilizers applied and also precipitation which directly changed the soil moisture content (Fig. 2). The emission of $\mathrm{N}_{2} \mathrm{O}$ was greater just after the first fertilization when much precipitation and a high content of soil moisture were observed. Also plant $\mathrm{N}$ uptake might be weak just after $1^{\text {st }}$ fertilization to compare with $2^{\text {nd }}$ fertilization. Therefore, the $\mathrm{N}_{2} \mathrm{O}$ flux peaked immediately after the first fertilization. Meanwhile, in the second fertilization, the precipitation and soil moisture were lower and the $\mathrm{N}_{2} \mathrm{O}$ flux increased gradually after the rain started about 50-55 DAF. $\mathrm{N}_{2} \mathrm{O}$ flux from the urea+DCD plot started to increase later than from other fertilized plots, indicating that inhibition by DCD of $\mathrm{N}_{2} \mathrm{O}$ production became less effective in that period. Akiyama and Tsuruta ${ }^{1)}$ also reported that the reduction of $\mathrm{N}_{2} \mathrm{O}$ emissions by DCD was effective only in aerobic conditions, partly due to the greater contribution of denitrification to $\mathrm{N}_{2} \mathrm{O}$ production under wet conditions ${ }^{15}$.

Soil water content before and after the rainfall presumably influenced the porosity and consequently increased the possibility of denitrification and also the diffusion of $\mathrm{N}_{2} \mathrm{O}$ out of the soil ${ }^{15)}$. Inubushi et al. ${ }^{15)}$ reported that at a water-holding capacity of $100 \%$, an enormous amount of $\mathrm{N}_{2} \mathrm{O}$ was produced rapidly in Andosols, mostly by denitrification. Khalil et al. ${ }^{21)}$ also suggested that rainfall and nitrogen input mainly regulated the amount of $\mathrm{N}_{2} \mathrm{O}$ emitted from an upland cropping system in the humid tropics of Malaysia. In addition, several reports $24,28,35)$ indicate nitrogen fertilizers to be one of the dominant sources of $\mathrm{N}_{2} \mathrm{O}$ emitted from agricultural soils as shown by our previous results ${ }^{19)}$.

The cumulative $\mathrm{N}_{2} \mathrm{O}$ emission per cropping season (October 17, 2005 to January 5, 2006) was highest in the urea plot at $1.87 \mathrm{~kg} \mathrm{~N}_{2} \mathrm{O}-\mathrm{N} \mathrm{ha}{ }^{-1}$ season $^{-1}$, followed by the CRF-LP30 plot at $1.70 \mathrm{~kg} \mathrm{~N}_{2} \mathrm{O}-\mathrm{N} \mathrm{ha}{ }^{-1}$ season $^{-1}$. Urea+DCD and control plots emitted 1.06 and $0.42 \mathrm{~kg} \mathrm{~N}_{2} \mathrm{O}-\mathrm{N} \mathrm{ha}{ }^{-1}$ season $^{-1}$, respectively. The urea plot had an emission factor (EF) of $1.61 \%$, compared to $1.42 \%$ in the CRF-LP30 plot and $0.71 \%$ in the urea+DCD plot.

The emission factor in soil from an Andisol amended with chemical fertilizers in a temperate region in Japan ranged from 0.05 to $0.32 \%{ }^{1)}$. These emission factors were slightly low compared with our results. In contrast, in acid oxisol in Puerto Rico, where a chemical fertilizer was also applied, emission factors ranged from 0.5 to $5 \%{ }^{29)}$. However, Watanabe et al. ${ }^{35)}$ reported that the application of $\mathrm{N}$ fertilizers in corn fields at four sites in Thailand at a rate of around $47-75 \mathrm{~kg} \mathrm{~N}^{-1}$ emitted $\mathrm{N}_{2} \mathrm{O}$ gas at 0.1 to $0.4 \%$. Mahmood et al. ${ }^{25)}$ suggested that the emission factors from an irrigated sandy-clay loam soil in a maize-wheat cropping system in subtropical Pakistan were around 30 to $45 \%$. Therefore, these emission factor values are mostly dependent on management practices, fertilizer types, and climatic and soil

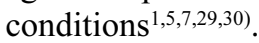

\section{Methane flux}

Initial measurements of $\mathrm{CH}_{4}$ (0-10 days) flux ranged from 0.05 to $0.13 \mathrm{mg} \mathrm{m}^{-2} \mathrm{~h}^{-1}$ across all treatments (Fig. 2). However after 10 days, no detectable amounts of $\mathrm{CH}_{4}$ were observed with any of treatments except urea in which the cumulative emission was $0.06 \mathrm{~kg} \mathrm{CH}_{4}-\mathrm{C} \mathrm{ha}^{-1}$ season $^{-1}$. The corn field acted as a sink for $\mathrm{CH}_{4}$ in the $\mathrm{CRL}$, Control, and urea+DCD plots with value of $-0.09,-0.06$ and $-0.06 \mathrm{~kg}$ $\mathrm{CH}_{4}-\mathrm{C}$ ha $^{-1}$ season $^{-1}$, respectively.

Slight $\mathrm{CH}_{4}$ production seemed to temporarily appear as positive peaks in the corn field soil, particularly in fertilized soil plots (Fig. 2). Le Mer and Roger ${ }^{23)}$ suggested that urea and ammonium usually inhibit atmospheric $\mathrm{CH}_{4}$ oxidation due to competition at the level of nitrification, a transfer of $\mathrm{CH}_{4}$-oxidizing activity towards nitrification, and the toxicity of $\mathrm{N}_{2} \mathrm{O}$ produced. However, cumulative $\mathrm{CH}_{4}$ fluxes throughout seasonal measurements in the corn field were also negative, indicating the soil acted mostly as a sink for $\mathrm{CH}_{4}$.

The uptake of atmospheric $\mathrm{CH}_{4}$ in upland soil is affected by a number of field management practices such as tillage and $\mathrm{N}$-application. In this study, chemical fertilizer reduced $\mathrm{CH}_{4}$ uptake in the urea plot where a positive $\mathrm{CH}_{4}$ flux was observed. Delmas et al. ${ }^{5}$ also reported a reduced $\mathrm{CH}_{4}$ sink strength in agricultural fields compared to savanna soil in the Congo. Flux rates in the Savanna averaged $-0.46 \mu \mathrm{g} \mathrm{CH}_{4}-\mathrm{C}$ $\mathrm{m}^{-2} \mathrm{~h}^{-1}$ while in agricultural soils they averaged around -0.33 $\mu \mathrm{g} \mathrm{CH}_{4}-\mathrm{C} \mathrm{m}^{-2} \mathrm{~h}^{-1}$. Mosier et al. ${ }^{29)}$ reported a sink of $\mathrm{CH}_{4}$ flux averaging $-1.2 \mu \mathrm{g} \mathrm{CH}_{4}-\mathrm{C} \mathrm{m}^{-2} \mathrm{~h}^{-1}$ in a sorghum field in a Oxisol soil near Isabela, Puerto Rico.

Our results indicated that the corn field could be a sink for $\mathrm{CH}_{4}$ gas. However, more study is needed to investigate the interactive effects of nitrification inhibitors on $\mathrm{N}_{2} \mathrm{O}$ and $\mathrm{CH}_{4}$ flux in different crops and land types in the tropics.

\section{Population of nitrifiers and $\mathrm{NH}_{4}{ }^{+}$and $\mathrm{NO}_{3}{ }^{-}$contents of soil}

AOB (ammonia-oxidizing bacteria) and NOB (nitrite-oxidizing bacteria) populations were counted 4 times during the first half of the crop season (Fig. 3). The number of nitrifiers in all plots at first measurement 16 days after the first application $(31 / 10 / 05)$ was around $1 \times 10^{3}$ cells $\mathrm{g}^{-1} \mathrm{DS}$ (dry soil) and slightly increased afterward particularly in the plots amended with fertilizer. However, they were still not significantly different from each other until 30 days after the fertilizers were applied.

The AOB counts peaked at the third measurement (50 days after fertilization) in the urea and CRF plots, while NOB tended to increase gradually in all fertilized plots. At 50 and 64 days, the number of NOB was significantly higher in soil amended with fertilizer. However, at the same time, the number of AOB did not differ between the control and urea+DCD plots, while it was significantly higher in the urea and CRF plots.

During corn cropping, nitrifiers seemed to be stimulated in the fertilizer-treated soil possibly as a result of the amount of inorganic nitrogen in the soils since fertilizer-treated soil had relatively high $\mathrm{NH}_{4}{ }^{+}$and $\mathrm{NO}_{3}{ }^{-}$contents compared to unfertilized soil (Fig. 4).

The $1^{\text {st }}$ application of $\mathrm{N}$ fertilizers increased the concentrations of $\mathrm{NH}_{4}{ }^{+}$and $\mathrm{NO}_{3}{ }^{-}$in the soil (Fig. 4). The level of $\mathrm{NO}_{3}{ }^{-}$ 4 and 20 days after first fertilization was significantly higher in the urea plot than the other plots, but no differences in $\mathrm{NH}_{4}{ }^{+}$content were found during that time. However, in the last measurements before the second fertilization (28 and 36 days after first fertilization), the level of $\mathrm{NH}_{4}{ }^{+}$was significantly higher in the CRF-LP30 plot than in the other plots, while the $\mathrm{NO}_{3}{ }^{-}$concentration did not differ significantly 

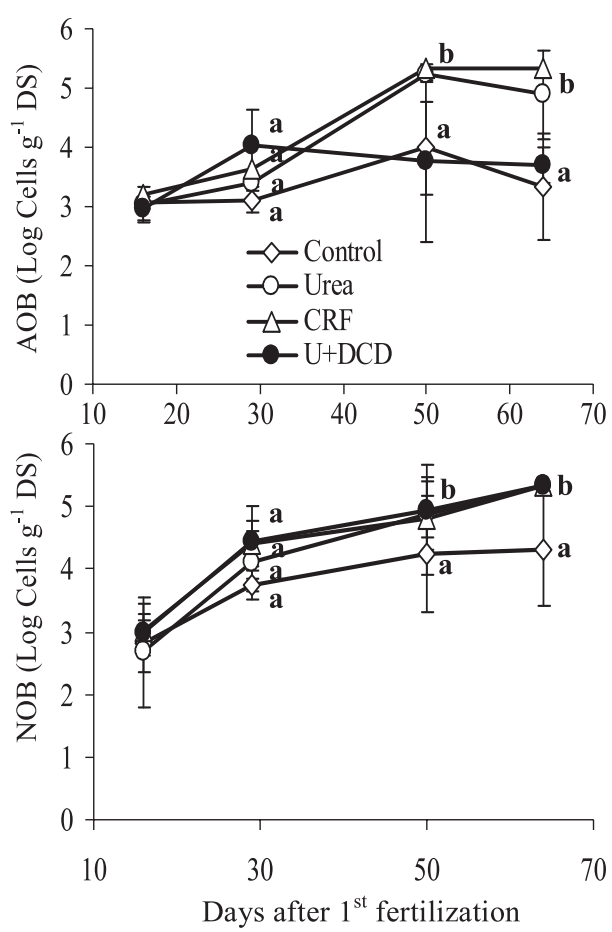

Fig. 3. Changes of the viable population of nitrifiers during the cropping season. Vertical bars indicate \pm standard deviation. Same letters are not significantly different at 5\% LSD. AOB (ammonia-oxidizing bacteria) and NOB (nitrite-oxidizing bacteria). See Fig. 1 for other abbreviations of symbols.

among plots.

The decrease in the $\mathrm{NH}_{4}^{+}$content of the soil was accompanied by an increased in $\mathrm{NO}_{3}{ }^{-}$content. The $\mathrm{NO}_{3}{ }^{-}$in the soils appeared within 4 days after urea was applied and this result was supported by Venterea and Rolston ${ }^{34)}$ who found $\mathrm{NO}_{3}{ }^{-}$ accumulated within 2 days in clay soil and the level of $\mathrm{NO}_{3}-$ increased over the first 4 days of incubation.

The concentration of $\mathrm{NH}_{4}{ }^{+}$remained higher in the CRF plot on 28 and 36 DAF compared to the other soils. Hou and Tsuruta ${ }^{14)}$ reported that CRF increased the amount of $\mathrm{NH}_{4}{ }^{+}$in an Andosol following fertilization and the level decreased afterwards. This delay could be partly explained by the hypothesis that a certain amount of time is needed for this fertilizer to release $\mathrm{NH}_{4}^{+}$and diffuse into the surrounding soil.

Urea+DCD seemed to have no impact on the $\mathrm{NH}_{4}{ }^{+}$content of the soil before the second fertilization while it reduced the $\mathrm{NO}_{3}{ }^{-}$content compared to urea alone 4 and 20 days after the first fertilization (Fig. 4). Francis et al. ${ }^{9}$ ) found that the application of DCD resulted in a greater amount of $\mathrm{NH}_{4}^{+}$at a depth of 1-2 cm and a lesser amount of $\mathrm{NO}_{3}{ }^{-}$at $1-4 \mathrm{~cm}$ in wheat leguminous pasture. The reason for the discrepancy in our experimental results is not clear, but DCD might need longer than 40 days to increase the $\mathrm{NH}_{4}{ }^{+}$content under these experimental conditions.

Positive correlations were observed between the cumulative emission of $\mathrm{N}_{2} \mathrm{O}$ and $\mathrm{AOB}$ counts at $64 \mathrm{DAF}\left(\mathrm{R}^{2}=0.854\right.$, $\mathrm{P}<0.05$ ) (Fig. 5). However, early on, the number of $\mathrm{AOB}$ was not significantly different probably due to delayed growth and also AOB have slower growth characteristic, therefore at that time the number was similar to the indigenous number
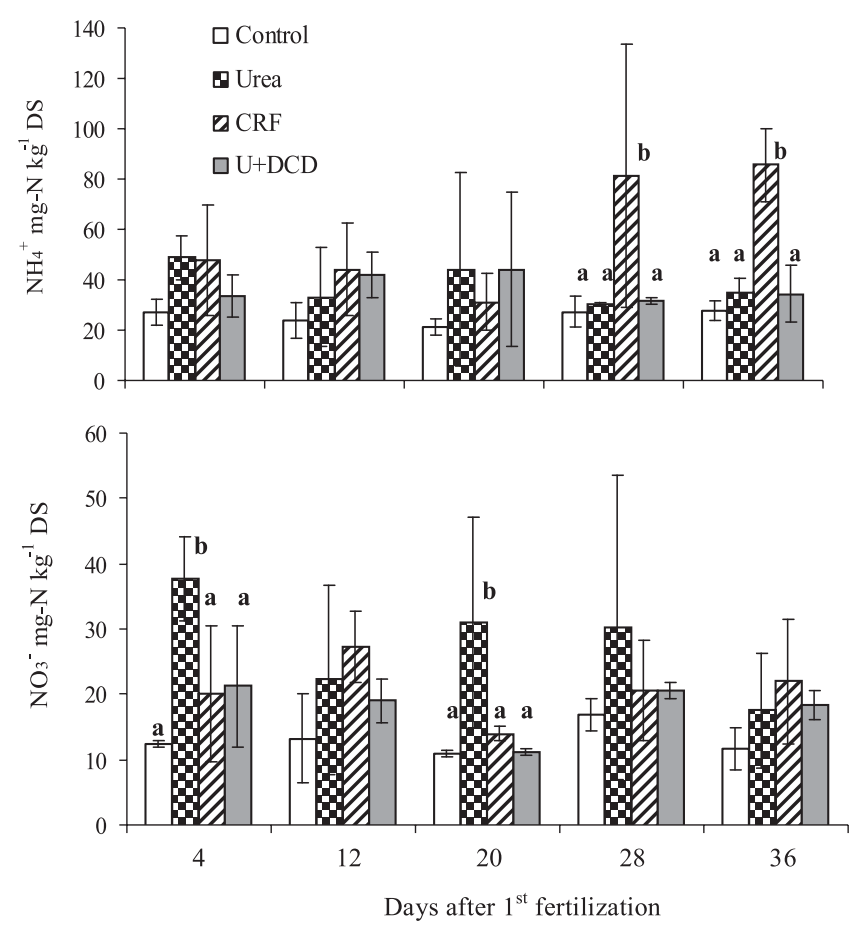

Fig. 4. Change of $\mathrm{NH}_{4}{ }^{+}$and $\mathrm{NO}_{3}{ }^{-}$in the corn field affected by different nitrogen fertilizers during the cropping season. Vertical bars indicate \pm standard deviation. At each sampling time for each soil, means followed by the same letter are not significantly different at $5 \%$ LSD. See Fig. 1 for abbreviations of symbols.

of AOB in the field. The results were supported by Martikainen ${ }^{27)}$ who reported that the numbers of AOB and NOB in pine forest soil increased on amendment with urea alone or together with apatite+biotite and with apatite+biotite+micronutrients. In addition, he also found that there was a correlation between the number of $\mathrm{AOB}$ and $\mathrm{NH}_{4}{ }^{+}-\mathrm{N}$ content in these pine forest soils.

The population of NOB was significantly larger in the fertilizer-treated plots than control plot 50 and 64 DAF, nearly at the end of cropping. NOB have been known to have slower growth rates in response to nitrogen amendment compared with the AOB population ${ }^{10,20)}$. As Venterea and Rolston $^{34)}$ reported, during nitrification, residual $\mathrm{NO}_{2}^{-}$ appeared and could induce the nitrifier population particularly $\mathrm{NOB}$ which preferentially grew where $\mathrm{NO}_{2}^{-}$was adsorbed as primary substrate.

Fukumoto et al. ${ }^{10)}$ reported a correlation of AOB and NOB numbers on the production of $\mathrm{N}_{2} \mathrm{O}$ and $\mathrm{NO}_{2}$ during pig manure composting, and suggested that the addition of NOB after the thermophilic phase of composting reduced $\mathrm{N}_{2} \mathrm{O}$ production and also the number of AOB compared to no addition of NOB. Moreover, the continuous culture of $\mathrm{AOB}$ and NOB together strongly reduced $\mathrm{N}_{2} \mathrm{O}$ production as an effect of the lower $\mathrm{NO}_{2}{ }^{20)}$.

The results of the present study showed that the type of nitrogen fertilizer influenced the emissions of $\mathrm{N}_{2} \mathrm{O}$ and $\mathrm{CH}_{4}$ from the corn field and affected the population of nitrifiers in the soil. Therefore, further detailed studies are needed to assess the structural communities of nitrifiers as affected by the application of different types of fertilizers in tropical field soils. 


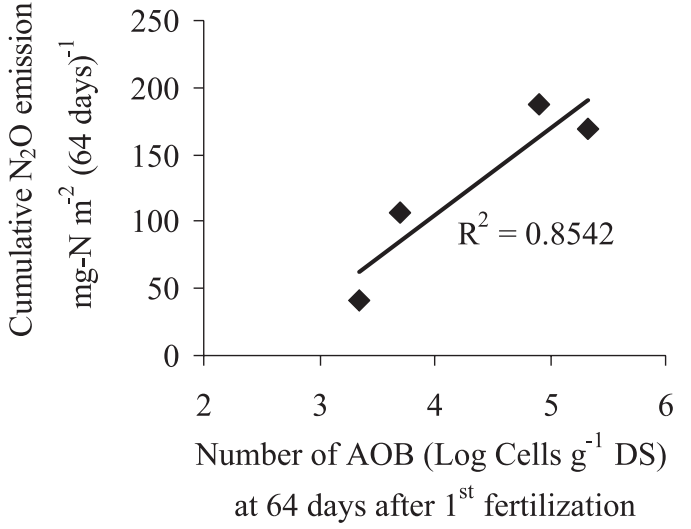

Fig. 5. Relationship between cumulative $\mathrm{N}_{2} \mathrm{O}$ flux and $\mathrm{AOB}$ (ammonia-oxidizing bacteria) counts 64 days after the first fertilization.

\section{Acknowledgements}

This study was supported by the GHG-SSCP project (S2-3a) of the Global Environment Research Fund by the Ministry of the Environment, Japan. We thank Dr. M. Tachibana of Chissoasahi Fertilizer Co., Ltd. for providing the fertilizer tested, and the editor-inchief and anonymous reviewers for their useful comments.

\section{References}

1) Akiyama, H., and H. Tsuruta. 2002. Effect of chemical fertilizer form on $\mathrm{N}_{2} \mathrm{O}$, $\mathrm{NO}$ and $\mathrm{NO}_{2}$ flux from an Andisol field. Nutr. Cycl. Agroecosyst. 63:219-230.

2) Anderson, J.M., and J.S.I. Ingram. 1989. Tropical Soil Biology and Fertility, pp. 42-43. Colometric determination of ammonium. ISSS, CAB International, Wallingford.

3) Arp, J.D., and L.Y. Stein. 2003. Metabolism of inorganic N compounds by ammonium-oxidizing bacteria. Critic. Rev. Biochem. Mol. Biol. 38:471-495.

4) Crecchio, C., M. Curci, R. Mininni, P. Ricciuti, and P. Ruggiero. 2001. Short-term effects of municipal solid waste compost amendments on soil carbon and nitrogen content, some enzyme activities and genetic diversity. Biol. Fertil. Soils 34:311-318.

5) Delmas, R., D. Serca, and C. Jambert. 1997. Global inventory of NOx sources. Nutr. Cycl. Agroecosyst. 48:51-60.

6) Di, H.J., and K.C. Cameron. 2002. The use of nitrification inhibitor, dicyandiamide (DCD), to decrease nitrate leaching and nitrous oxide emissions in a simulated grazed and irrigated grassland. Soil Use Manage. 18:395-403.

7) Dobbie, K.E., and K.A. Smith. 2003. Impact of different form of $N$ fertilizer on $\mathrm{N}_{2} \mathrm{O}$ emissions from intensive grassland. Nutr. Cycl. Agroecosyst. 67:37-46.

8) Foster, J.C. 1995. Soil physical analysis, pp. 105-106. In K. Alef and Nannipieri (ed.), Methods in Applied Soil Microbiology and Biochemistry. Academic Press. London.

9) Francis, G.S., R.J. Haynes., T.W. Speir, and P.H. Williams. 1995. The effect of a nitrification inhibitor on leaching losses and recovery on mineralized nitrogen by a wheat crop after ploughing-in temporary leguminous pasture. Fert. Res. 41:33-39.

10) Fukumoto, Y., K. Suzuki, T. Osada, K. Kuroda, D. Hanajima, T. Yasuda, and K. Haga. 2006. Reduction of nitrous oxide emission from pig manure composting by addition of nitrite-oxidizing bacteria. Environ. Sci. Technol. 40:6787-6791.

11) German-Bauer, M.P., and A. Amberger. 1989. Degradation of the nitrification inhibitor 1-amidino-2-thiourea in soils, and its action in Nitrosomonas pure culture and soil incubation experiments. Fert. Res. 19:13-19.

12) Hayashi, A., K. Sakamoto, and T. Yoshida. 1997. A rapid method for determination of nitrate in soil by hydrazine reduction procedure. Jpn. J. Soil Sci. Plant Nutr. 68:322-326 (In Japanese).

13) Hou, A.X., H. Akiyama, Y. Nakajima, S. Sudo, and H. Tsuruta. 2000. Effects of urea form and soil moisture on $\mathrm{N}_{2} \mathrm{O}$ and $\mathrm{NO}$ emissions from Japanese Andosols. Chemosphere: Global Sci. Change. 2:321327.

14) Hou, A.X., and H. Tsuruta. 2003. Nitrous oxide and nitric oxide fluxes from an upland field in Japan: effect of urea, placement, and crop residues. Nutr. Cycl. Agroecosyst. 65:191-200.

15) Inubushi, K., H. Naganuma, and S. Kitahara. 1996. Contribution of denitrification and autotrophic and heterotrophic nitrification to nitrous oxide production in andosols. Biol. Fertil. Soils 23:292-298.

16) Inubushi, K., Y. Furukawa, A. Hadi, E. Purnomo, and H. Tsuruta. 2003. Seasonal change of $\mathrm{CO}_{2}, \mathrm{CH}_{4}$ and $\mathrm{N}_{2} \mathrm{O}$ fluxes in relation to land-use change in tropical peatlands located in coastal area of South Kalimantan. Chemosphere 52:603-608.

17) Inubushi, K., and S. Acquaye. 2004. Role of microbial biomass in biogeochemical processes in paddy soil environments. Soil Sci. Plant Nutr. 50:793-805.

18) Jiang, Q.Q., and L.R. Bakken. 1999. Nitrous oxide and methane oxidation by different ammonium-oxidazing bacteria. Appl. Environ. Microbiol. 65:2679-2684.

19) Jumadi, O., Y. Hala, and K. Inubushi. 2005. Production and emission of nitrous oxide and responsible microorganisms in upland soil in Indonesia. Soil Sci. Plant Nutr. 51:693-696.

20) Kester, R.A., W.D. Boer, and H.J. Laanbroek. 1997. Production of $\mathrm{NO}$ and $\mathrm{N}_{2} \mathrm{O}$ by pure culture of nitrifying and denitrifying bacteria during change in aeration. Appl. Environ. Microbiol. 63:3872-3877.

21) Khalil, M.I., O.V. Cleemput, A.B. Rosenani, and U. Schmidhalter. 2007. Daytime, temporal, and seasonal variations of $\mathrm{N}_{2} \mathrm{O}$ emissions in an upland cropping system of the humid tropics. Comm. Soil Sci. Plant Anal. 38:189-205.

22) Kowalchuk, G.A., and J.R. Stephen. 2001. Ammonia-oxidizing bacteria: a model for molecular microbial ecology. Annu. Rev. Microbiol. 55:485-529.

23) Le Mer, J., and P. Roger. 2001. Production, oxidation, emission and consumption of methane by soil: A review. Eur. J. Soil Biol. 37:2550

24) Li, X., K. Inubushi, and K. Sakamoto. 2002. Nitrous oxide concentration in an Andisol profile and emissions to the atmosphere as influenced by the application of nitrogen fertilizers and manure. Biol. Fertil. Soils 35:108-113.

25) Mahmood, T., K.A. Malik, S.R.A. Shamsi, and M.I. Sajjad. 1998. Denitrification and total $\mathrm{N}$ losses from an irrigated sandy-clay loam under maize-wheat cropping system. Plant Soil 199:239-250.

26) Majumdar, D., H. Pathak, S. Kumar, and M.C. Jain. 2002. Nitrous oxide emission from a sandy loam inceptisol under irrigated wheat in India as influenced by different nitrification inhibitors. Agri. Ecosyst. Environ. 91:283-293.

27) Martikainen, P.J. 1985. Number of autotrophic nitrifiers and nitrification in fertilized forest soil. Soil Biol. Biochem. 17:245-248.

28) Mosier, A.R., and C. Kroeze. 2000. Potential impact on the global atmospheric $\mathrm{N}_{2} \mathrm{O}$ budget of the increased nitrogen input required to meet future global food demands. Chemosphere-Global Change Sci. 2:465-473.

29) Mosier, A.R., J.A. Delgado, and M. Keller. 1998. Methane and nitrous oxide fluxes in an acid Oxisol in western Puerto Rico: Effect of tillage, liming and fertilization. Soil Biol. Biochem. 30:2087-2098.

30) Robertson, G.P., and J.M. Tiedje. 1987. Nitrous oxide source in aerobic soils: Nitrification, denitrification and other biological processes. Soil Biol. Biochem 19:187-193.

31) Sarathchandra, S.U., A. Ghani, G.W. Yeates, G. Burch, and N.R. Cox. 2001. Effect of nitrogen and phosphate fertilizers on microbial and nematode diversity in pasture soils. Soil Biol. Biochem. 33:953964.

32) Schmidt, E.L., and L.W. Belser. 1982. Nitrifying bacteria, pp. 10271042. In D.R. Keeney (ed.), Method of Soil Analysis, part 2. Soil Science of American. Madison, WI, U.S.A.

33) Schimel, J.P., and J. Gulledge. 1998. Microbial community structure and global trace gases. Global Change Biol. 4:745-758.

34) Venterea, R.T., and D.E. Rolston. 2000. Mechanisms and kinetic of nitric and nitrous oxide production during nitrification in agricultural soil. Global Change Biol. 6:303-316.

35) Watanabe, T., P. Chairoj, H. Tsuruta, W. Masarngsan, C.W. Wiwatchai, S. Wonprasaid, W. Cholitkul, and K. Minami. 2000. Nitrous oxide emission from fertilized upland field in Thailand., Nutr. Cycl. Agroecosyst. 57:55-65. 